\title{
Importance Performance Analysis of Halal Tourism Destination in the Province of Bangka Belitung Archipelago
}

\author{
Reniati Reniati \\ Department Managemen Faculty of Economics \\ Universitas Bangka Belitung \\ Bangka Belitung, Indonesia \\ r3ni4ti@yahoo.com
}

\author{
Nanang Wahyudin, Khairiyansayah \\ Department Managemen Faculty of Economics \\ Universitas Bangka Belitung \\ Bangka Belitung, Indonesia \\ nanang.w19@gmail.com , \\ khairiyansyah.supendi@gmail.com
}

\begin{abstract}
Destination: The purpose of this research is to find out and analyze the Tourism Development Strategy in the Province of Bangka Belitung Islands, to study the marketing strategy, global benchmarking, capacity building and the performance of MSMEs supporting the tourism sector.

Research Methodology: The analytical method used is IPA Analysis and PLS, while the sample used is 80 people with locations on Bangka Island and Belitung Island.

Limitations: The difficulty of getting foreign tourists, pandemic conditions made it difficult for researchers at the interview stage, and the number of tourists that decreased significantly had an impact on the survey and interview process.
\end{abstract}

Keywords: Halal Tourism, Global Benchmarking, Capacity Building

\section{INTRODUCTION}

Religion is one of the most extensive social institutions and has a significant influence on the values, behavior and attitudes of society in general and individuals in particular (Mokhlis, 2009). Religiosity explains the idea of a pattern of life that can be seen based on the attitudes and values of individuals and society (Fam, Waller, \& Erdogan, 2004).

Religion has long been a strong motivating factor in people's travel (Wall \& Mathieson, 2006). Therefore, tourism and religion are closely related as has been discussed in the literature on tourism in various ways. (eg. Battour, Ismail, \& Battor, 2010; Idul Fitri \& El-Gohary, 2015a, 2015b, 2014; ElGohary \& Idul Fitri, 2014; Henderson, 2011; Jafari \& Scott, 2014).

However, it should be noted that previous research on the various viewpoints of serious religious tourism has been limited because religion is one of the relatively underrepresented and under-researched areas of tourism. Religion has long had a strong influence on tourism (Wall \& Mathieson, 2006). In addition, given that tourism is a industry of sosial and cultural, it should then closely represent the dimensions of ethnicity and religion (Stephenson, Russell, \& Edgar, 2010).

Responding to development of the current era, tourism industry is moving away from mass marketing and finding a more sophisticated approach to segmenting the tourism market in order to deal with consumer psychology which is certainly different from certain markets.
Increasing the tourism industry globally creates a comprehensive understanding of the importance of understanding preferences, interests and attitudes (Han, Yu, \& Kim, 2018). This creates high competitiveness for international destinations to develop strategic marketing plans and tools to improve the performance of the tourism industry in the global arena and achieve high levels of tourism success (Bornhorst, Ritchie, \& Sheehan, 2010). The rapid growth of halal tourism has become a vital alternative market segment for many international tourist destinations in recent years (Ryan, 2016).

According to (Henderson: 2010) research, literally Halal means "lawful" or "permitted". Halal is Islamic faith and is more than just about food products; it includes various types of services and products offered to the Muslim population. Halal can be defined as lawful or permissible under Shari'ah; it is a credence quality attribute (Jafari \& Scott, 2014). Therefore, it can be understood that halal tourism is a sector that seeks to support the essential values of islam.

Halal tourism is a concept that includes components such as halal tour packages, halal food, tourism, and halal hotels (El-Gohary, 2016). Muslim tourists who are concerned about the availability of Halal products and services often face difficulties in non-Muslim countries (Battour \& Ismail, 2016). Halal tourism has a main focus on meeting the needs of Muslim consumers, such as alcohol-free drinks, foods containing halal meat, and access to restaurants that are free of gambling (Henderson, 2016).

FICCI Religious Tourism Report (2012) classified religious tourism into the following major categories:

a) Pilgrimages.

b) Missionary travel.

c) Leisure (fellowship) vacations.

d) Faith-based cruising.

e) Crusades, conventions and rallies.

f) Retreats.

g) Monastery visits and guest-stays.

h) Faith-based camps.

i) Religious tourist attractions (FICCI, 2012, p: 3).

Halal tourism is also a new phenomenon that comes from the growth of the halal industry. Many Muslim and nonMuslim countries are preparing themselves to capture the halal 
tourism market with a strategy of providing facilities and infrastructure, as well as products that can meet the needs of Muslim tourists, along with progress related to halal issues in the world of the tourism industry.

No doubt about it for a Muslim, guidelines for all aspects of human activity including travel are written in the Alquran. There are several terms on tourism in the Quran. The common expression is the word al-fasih as contained in this verse that says,

"Go ye, then, for four months, backwards and forwards, (as ye will), throughout the land, but know ye that ye cannot frustrate Allah (by your falsehood) but that Allah will cover with shame those who reject Allah. "

(Surah al-Maa'idah: 3).

The category of travel enjoined in Islam can be described as "purposeful" tourism as distinct from the general practice of mass tourism which is motivated primarily by pleasure and hedonistic pursuits. Indeed, the official definition of "tourist" does not include those who work, whereas in Islam work (trade) is encouraged as for example during the pilgrimage season. The secular meaning of tourism also implies a vacation or non-work engagement which is a form of casual diversion from work situations. Vacation travel is intended to be a relaxing and refreshing experience (Din, 1989; Sanad, Kassem, \& Scott, 2010).

As a result, various countries have provided alternative solutions, namely developing tourism facilities for the convenience of tourists, especially Muslim tourists. One of the countries participating in the construction of tourism facilities is in Indonesia.

Indonesia has many areas that have tremendous tourism potential and must be better managed immediately so that tourism can compete at the international level. Moreover, Indonesia is a very suitable place to be a choice for Muslim tourists to have a vacation. One of the regions in Indonesia that is the best choice for developing halal tourism is the Province of Bangka Belitung Islands.

The province of Bangka Belitung Islands, as an area that is starting to grow its tourism sector, has the opportunity to develop halal tourism. Starting in 2010, the Pre Visit Babel Archipelago era had 92. 413 visits, and after 2010 since the establishment of Visit Babel Archipelago the number of visits in 2015 reached 260,930 with the number of foreign tourists 3,335. And when the establishment of the Tanjung Kelayang \& Geopark SEZ on Belitung Island, the number of visits in 2018 reached 425,942 with the number of foreign tourists increasing sharply by 8,124 . In 2019 there was an increase of 438,774 and the number of foreign tourists 9,183 .

To make Babylon as one of the halal tourist destinations, there are still many things that need to be prepared, starting from accessibility, communication, environment and services for tourists. Halal tourism requires a good halal industrial ecosystem, Sofyan ConsultingAnalysis (2020) The portfolio of Halal tourism products in Indonesia consists of three components, namely nature $35 \%$, culture $60 \%$ and manmade $5 \%$. To make a strategy for Halal Tourism in the Province of Bangka Belitung Islands, it is necessary to know the potential and development that has been done so far. This is in order to prepare a halal industrial ecosystem. Then after that it is necessary to carry out a marketing strategy, promotion and branding as well as global benchmarking of halal tourism

\section{RESEARCH METHODOLOGY}

\section{A. Research Design}

The design of this research is in the form of primary and secondary data about the tourism industry in the Province of Bangka Belitung Islands, by interviewing domestic tourists, foreign tourists, MSMEs, hotels, restaurants, travel, related agencies and festival event organizers, academics related to matters related to destinations tourism, halal tourism facilities, community participation, policies, marketing, capital and human resources.

\section{B. Data Analysis Techniques}

The analysis technique uses two analytical tools, namely Partial Least Square to test the Strategy Model created and Importance Performance Analysis.

\section{RESEARCH RESULT}

A. Analysis of the Level of Suitability

Analysis of the Level of Suitability of Importance and Performance (Per-Variable) Per-Variable Conformity Level, can be seen in the following table :

TABLE 1. CONFORMITY LEVEL ANALYSIS

\begin{tabular}{|c|c|c|c|c|c|}
\hline No & Variable & $\begin{array}{c}\text { Impor } \\
\text { tant }\end{array}$ & $\begin{array}{l}\text { Perfor } \\
\text { mance }\end{array}$ & $\begin{array}{l}\text { Tki } \\
(\%)\end{array}$ & $\begin{array}{l}\text { IKP = } \\
\text { SIxSP }\end{array}$ \\
\hline 1 & Halal Digital Economy & 4.38 & 3.71 & 84.70 & 16.25 \\
\hline 2 & $\begin{array}{l}\text { Rise of Muslim Female } \\
\text { Travelers }\end{array}$ & 4.35 & 3.91 & 89.89 & 17.01 \\
\hline 3 & $\begin{array}{l}\text { Asian Destination } \\
\text { Leadership }\end{array}$ & 4.50 & 4.12 & 91.56 & 18.54 \\
\hline 4 & $\begin{array}{l}\text { Development of The } \\
\text { Halal Travel } \\
\text { Ecosystem }\end{array}$ & 4.57 & 3.89 & 85.12 & 17.78 \\
\hline 5 & $\begin{array}{l}\text { Muslim Friendly } \\
\text { Tourist Services }\end{array}$ & 4.82 & 3.60 & 74.69 & 17.35 \\
\hline 6 & $\begin{array}{l}\text { Content Discovery \& } \\
\text { Experiences Halal }\end{array}$ & 4.12 & 3.29 & 79.85 & 13.55 \\
\hline 7 & $\begin{array}{l}\text { Spreading Travelers } \\
\text { Visual Stories }\end{array}$ & 4.14 & 4.00 & 96.62 & 16.56 \\
\hline 8 & $\begin{array}{l}\text { Artificial Intelligent } \\
\text { (AI) in The } \\
\text { Development of Halal } \\
\text { Travel Solution }\end{array}$ & 4.19 & 3.25 & 77.57 & 13.62 \\
\hline 9 & $\begin{array}{l}\text { Brand Empathy to } \\
\text { connect with Muslim } \\
\text { travelers }\end{array}$ & 3.81 & 3.04 & 79.79 & 11.58 \\
\hline 10 & $\begin{array}{l}\text { Sustainability and } \\
\text { Community Initiatives }\end{array}$ & 4.31 & 3.34 & 77.49 & 14.40 \\
\hline \multicolumn{2}{|r|}{ Total } & 43.19 & 36.15 & 837.28 & 156.6 \\
\hline \multicolumn{2}{|r|}{ Average } & 4.32 & 3.62 & 83.73 & \\
\hline
\end{tabular}

Source: Data processed in 2020

In this variable, which has the lowest conformity level value lies in the variable Muslim Friendly Tourist Services amounting to 74.69 , while the highest level of suitability lies in the indicator found at Spreading Travelers Visual Stories 
(spreading tourist visuals) of $96.62 \%$. Overall, the value of the level of conformity to these variables was $83.73 \%$.

\section{B. Cartesian Diagram Analysis}

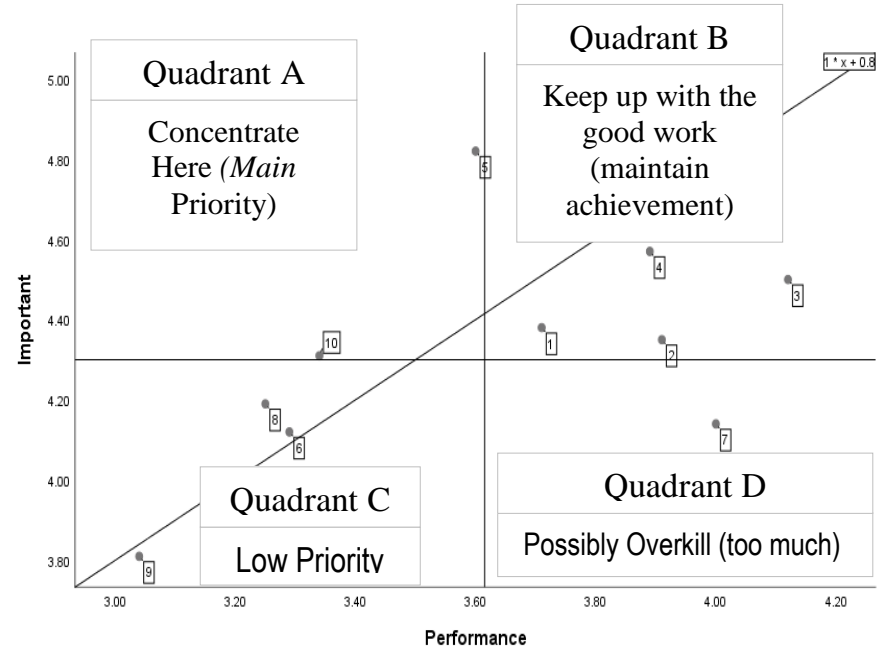

Source: Data processed in 2020

Image 1. Cartesian diagram Analysis

The interpretation of the Cartesian diagram is as follows: Quadrant A (Main priority)

The variables contained in this quadrant have 2 variables, namely:

- Muslim Friendly Tourist Services (item 5)

It shows that these variables have a low service reality but high expectation levels, so that there needs to be an increase in Muslim-friendly tourism services so that religious tourists get good service or in accordance with expectations and can develop halal tourism in Bangka Belitung province

- Sustainability and Community Initiatives (item 10)

This variable explains that the level of performance is still low while the level of expectations is high, so it is necessary to get the first priority for improvement. The community actively contributes to environmental conservation and provides ideas for sustainable development in order to promote and develop halal tourism in the province of Bangka Belitung.

\section{Quadrant B (Maintain Achievement)}

The variables contained in this quadrant have 4 variables, namely:

- Halal Digital Economy (item 1)

- Rise of Muslim Female Travelers (item 2)

- Asian Destination Leadership (item 3)

- Development of The Halal Travel Ecosystem (item 4)

\section{Quadrant C (Low Priority)}

The variables contained in this quadrant have 3 variables, namely:
- Content Discovery \& Experiences Halal (item 6)

- Artificial Intelligent (AI) in The Development of Halal Travel Solution (item 8)

- Brand Empathy to connect with Muslim travelers (item 9)

\section{Quadrant D (Excessive)}

The variables contained in this quadrant have 1 variable, namely: Spreading Travelers Visual Stories (item 7)

\section{Satisfaction Index}

The decision of consumers or visitors is certainly different. To see the level of visitor decision, the customer satisfaction index analysis is used

$$
\begin{gathered}
\text { Customer Satisfaction Index }=\frac{\sum \text { SIxSP }}{\sum \text { SIx } 5} \times 100 \% \\
\text { IKP }=\frac{\sum 156,64}{\sum 43,19 \times 5} \times 100 \% \\
\text { IKP }=72.53 \%
\end{gathered}
$$

Based on the results of the calculation of all variables that have been carried out, it can be seen that the customer satisfaction index for halal tourism services in Bangka Belitung province is $72.53 \%$, it can be said that the level of customer satisfaction is in the satisfied category

\section{CONCLUSIONS AND SUGGESTIONS}

Based on the research stages, the implementation of this research has been completed, namely the collection of secondary data, primary data through interviews, surveys using google form and FGDs have been carried out both on the island of Bangka and on the island of Belitung which is in collaboration with Bank Indonesia. As for the achievement of the three planned output targets, all of them have not been implemented, the mandatory output in the form of international journals has been at the Accepted stage, while additional output is still in the process of analysis and drafting of scientific articles. The obstacles in this survey are the difficulty in getting foreign tourists, pandemic conditions make it difficult for researchers at the interview stage, and the number of tourists that has decreased significantly has an impact on the survey and interview process.

\section{ACKNOWLEDGMENT}

We would like to thank the Universitas Bangka Belitung for providing funding through the 2020 grant Penelitian Dosen Tingkat Jurusan (PDTJ)

\section{REFERENCES}

[1] Abror Abror, Yunia Wardi, Okki Trinanda \& Dina Patrisia (2019) The impact of Halal tourism, customer engagement on satisfaction: moderating effect ofreligiosity, Asia Pacific Journal of Tourism Research, 24: 7, 633-643, DOI: 10.1080 / 10941665.2019.1611609

[2] AlfonsoVargas-Sánchez, María Moral-Moral, (2018) "Halal tourism: stateoftheart", Tourism Review, https://doi.org/10.1108/ TR-01-20180015

[3] Al-Qardawi, Y. (1997). The LawfulandtheProhibited in Islam: Islamic Book Trust. Kuala Lumpur: El Falah.

[4] Andi Field, Discovering Statistics using SPSS, Second Edition (California: SAGE Publication, 2006) 
[5] Battour, M.M., Ismail, M.N., \& Battor, M. (2010). Toward a Halal tourism market. Tourism Analysis, 15(4), 461-470.

[6] Battour, M., \& Ismail, MN, Halaltourism: Concepts, practices, challenges and future, Tourism Management Perspectives (2015), http://dx.doi.org/10.1016/j.tmp.2015.12.008

[7] Bornhorst, T., Ritchie, J. B., \& Sheehan, L. (2010). Determinants of tourism success for DMOs and destinations: An empirical examination of stakeholders' perspectives. Tourism Management, 31(5), 572-589.

[8] Destiana Riska and Astuti Retno Sunu, (2019),DevelopmentHalal Tourism in Indonesia, Conferenceon Public Administration and Society. Volume 01, Number 01

[9] Din, K. H. (1989). Islam and tourism. Annals of Tourism Research, $16(4), 542-563$.

[10] Eid, R., \& El-Gohary, H. (2014). Testing and validating customer relationship management implementation constructs in Egyptian tourism organizations. Journal of Travel \& Tourism Marketing, 31(3), 344-365.

[11] Eid, R., \& El-Gohary, H. (2015a). The role of Islamic religiosity on the relationship between perceived value and tourist satisfaction. Tourism Management, 46(Feb), 477-488.

[12] Eid, R., \& El-Gohary, H. (2015b). Muslim tourist perceived value in the hospitality and tourism industry. Journal of Travel Research. http://dx.doi.org/10.1177/ 0047287514532367 (in press).

[13] El-Gohary, H., \& Eid, R. (2014). Emerging research on Islamic marketing and tourism in the global economy. IGI Global: USA (ISBN: 9781466662728).

[14] El-Gohary, H. (2016). Halal tourism, is it really halal? Tourism Management $\quad$ Perspectives, $19, \quad 124-130$. https://doi.org/10.1016/J.TMP.2015.12.013.

[15] Fam, K.S., Waller, D.S., \& Erdogan, B.Z. (2004). The influence of religion on attitudes towards the advertising of controversial products. European Journal of Marketing, 38(5/6), 537-555.

[16] FICCI Religious Tourism Report (2012). Diverse beliefs: Tourism of faith religious tourism gains ground. found at
http://www.ficci.com/spdocument/20207/Diverse-Beliefs-Tourism-ofFaith.pdf (accessed on: 30/12/2020)

[17] Han, H., Yu, J., \& Kim, W. (2018). Youth travelers and waste reduction behaviors while traveling to tourist destinations. Journal of Travel \& Tourism Marketing, 35(9), 1119-1131.

[18] Henderson, J. C. (2010). Sharia-compliant hotels. Tourism and Hospitality Research, 10(3), 246-254.

[19] Henderson, J. C. (2016). Halal food, certification and Halal tourism: Insights from Malaysia and Singapore. Tourism Management Perspectives, 19, 160-164. https://doi.org/10.1016/J.TMP.2015.12.006.

[20] Jafari, J., \& Scott, N. (2014). Muslim world and its tourisms. Annals of Tourism Research, 44, 1-19.

[21] John A. Martillaand John C. James, "Importance-Performance Analysis" (Journal of Marketing, January, 1977) pp. 77 - 79.

[22] Khotimah Khusnul, Hakim Luchman, (2017) Development Strategy for Cultural Tourism Destinations (Case Study of the Trowulan Site Area as Leading Cultural Tourism in Mojokerto Regency) Journal of Business Administration (JAB) | Vol. 41 No.1 January

[23] Mohsin, A., Ramli, N., \& Alkhulayfi, BA (2016). Halal tourism: Emerging opportunities. Tourism Management Perspectives, 19 (Part B), 137-143. doi: 10.1016 / j.tmp.2015.12.010

[24] Mokhlis, S. (2009). Relevancy and measurement of religiosity in consumer behavior research. International Business Research, 2(3), 7584.

[25] Ryan, C. (2016). Halal tourism. Tourism Management Perspectives, 19, 121-123.

[26] Stephenson, L., Russell, K., \& Edgar, D. (2010). Islamic hospitality in the UAE: Indigenization of products and human capital. Journal of Islamic Marketing, 1(1), 9-24.

[27] Wall, G., \& Mathieson, A. (2006). Tourism: change, impacts and opportunities. Essex: Pearson Prentice Hall. 